\title{
Sustainability of Buke Palang Pintu Tradition in Betawi Modern Society in Jakarta
}

\author{
A A Ningrum ${ }^{1,2}$ and $M$ Yoesoef ${ }^{1}$ \\ ${ }^{1}$ Departement of Literature, Faculty of Humanities, University of Indonesia, Indonesia \\ ${ }^{2}$ The National Agency for Language Development and Cultivation, Ministry of Education and \\ Culture, Indonesia \\ anita.astriawatiningrum@gmail.com
}

\begin{abstract}
Tradition usually considered as something ancient, outdated, not functional and not desirable anymore because it is not worth attending in the present on their community. In fact, tradition should be remembered as something which does not always appear in the same form as in the past or as narrated by the informant as something that has happened so in the past. Tradition may appear in its changed form or in its transformation form, but as a whole part are still recognizable in its traditional traces from the past. Tradition changed as people and community changed. This study discusses how Buke Palang Pintu as one of Betawi traditions are able to maintain their sustainability to keep alive and develop in the midst of Betawi community and Jakarta residents with. This study uses qualitative research methods and oral trandition approach. The results of this study indicates that Buke Palang Pintu has changed it several elements. The changed itself are conduct by many reasons to maintain the sustainability of the traditions. The changed are also related to the condition of Betawi community and Jakarta residents where Buke Palang Pintu tradition lives.
\end{abstract}

Keywords: Tradition; Betawi; Buke Palang Pintu; Sustainability

\section{INTRODUCTION}

Sims and Stephen [1] define tradition as "(1) Both the lore we share and the process by which we share it; (2) something that creates and confirm identity; and (3) something that the group identifies as a tradition". Based on the details, tradition is presented as something shared by a community. Something is created and confirmed as an identity by the community. Tradition refers to something that has long existed and become the property as well as marking a community or a group of people.

The concept of tradition refers to a local knowledge possessed by a group of people with such knowledge as well as the process of transmitting that knowledge. This means that tradition also includes all processes that make a "tradition" a "tradition". For example, a story, a 
storytelling process, and various processes that make the story and story telling meaningful to the owner community are important to note when talking about tradition.

Tradition often contrasted with modern or actual things. In that case tradition is considered something ancient, outdated, not functional and not desirable anymore because it is not worth attending in the present. In fact, in its development, tradition does not always appear in the same form as in the past. Tradition may appear in its changed form or in the form of its transformation, but as a whole it is still recognizable of its traditional traces in the past. In other words, tradition should be viewed as a force which is capable to have a dialogue with other forces, including hegemony, outside of itself [2]. Tradition should not be seen as antiquities that have to be preserved, frozen, which are from the past and never allowed to change which is then exalted and immortalized. Tradition can not be separated away from the development of the community of the tradition. The dynamics of society will impact the survival of tradition and vice versa.

Betawi culture born from the process of acculturation diverse cultures and then grow with high contact with other cultures. Considering its position that inhabit the capital city of the country and the center of the economy, Betawi has a dynamics that is much more complex than the community owners who live in remote areas from the city center. The dynamics in Betawi society is certainly influent the growing of tradition. This dynamic of Betawi tradition can be looked in the development of the Buke Palang Pintu tradition.

\section{METHOD}

As a qualitative study, the research will describe the strategy to sustain Buke Palang Pintu tradition which is carried out by Betawi community as the perpetrator and owner of the tradition in relation to the complex conditions of Jakarta. This is in line definition qualitative research which intends to understand the phenomenon of what is experienced by research subjects (eg behavior, perception, motivation, actions, etc.) holistically and by describing phenomena in the form of words and language, in a special scientific context and by utilizing various scientific methods.

In conducting research, there are several techniques carried out to obtain data. First, literature review. The literature review was conducted to find as much literature as possible about the Buke Palang Pintu tradition, Betawi culture, and the history of Jakarta as well as the concepts used in this study. Second, observation. The observation technique is done so that the researcher gets an accurate description of the data to be taken. Observations were made by watching the Buke Palang Pintu show directly. Watching live performances is very important in the framework of oral tradition research because performances are a gateway to understanding an oral tradition. Witnessing performances allows researchers to see and observe the implementation of traditions and record behaviors and events as they did in the actual situation. By watching the show, the researcher can also record the things that appear in the performance. During the observation, documentation is done both visually, audio, and audio-visual that produces data in the form of photos, sound recordings, and video recordings during the performance. Documentation is an important part of the oral tradition research method because the documentation will complete the notes made during the field research. The documentation can be played back to then transcribed and analyzed. 


\section{RESULT AND DISCUSSION}

Buke Palang Pintu is one of Betawi tradition in marriage [3]. Buke Palang Pintu refers to the procession where the groom arrived at the bride's place. In Betawi wedding tradition, the groom can not just enter the house or place of marriage ceremony but must first face the "palang pintu" in the form of representatives of the bride who will challenge the groom by competing pantun, maen pukul, and singing sike. If the groom able to defeat the bride's representation then the groom are allowed to enter the house At present, Buke Palang Pintu is not only performed at wedding ceremonies but also during circumcision and inauguration (building, event).

Throughout the observations, changes in the Buke Palang Pintu tradition encompass a number of things, such as the shifting of tradition from its position as a ritual in the tradition of marriage to ceremonies, changes in elements such as the use of musical accompaniment and the contents of the pantun. The change is certainly not without motive and purpose. On the other hand, a form of tradition must have a standard, a provision, or a convention that is closely related to the symbols and understanding of the community to many things. When a tradition undergoes a change, it is not impossible, it can also describe the change in the mindset of people in the culture concerned. Therefore, this article will focus on how the development and change of Buke Palang Pintu as one of the Betawi traditions in the midst of the condition of Jakarta and its population is so complex. The description of the changes that appear in the Buke Palang Pintu tradition will be a gateway to understand the elements which is always appear (conservative elements) and what elements are dynamic and changing (dynamic elements).

Performances is a very important link in tradition. Only through performances a tradition can be understood. At the same time a performance becomes the source of the ongoing text [4]. The dynamic development of the Buke Palang can easily be seen in today's performance. Seeing the dynamics of an oral tradition through its performances according to Vansina becomes important considering the show is the source of the ongoing text. Vansina also saw that a show is a normal embodiment of a tradition as a whole. The condition of the performance is the condition of the tradition itself. The performance conditions referred to by Vansina relate to the frequency, time, and place of the performance. In addition to be done at certain times, the location of the show must also be in accordance with the purpose and purpose of the show. The performance time will also affect the show frequency. The frequency of performances is thought to help prevent forgetfulness or even extinction. However, the frequency of performances also does not guarantee the accuracy of a performance. For example, stories told over and over in a month may change more quickly than rarely told stories.

In connection with research on the change in Buke Palang Pintu tradition, the important points of performance as presented are the starting points for understanding how actually the dynamics in Buke Palang Pintu as a performance and tradition, especially in view of the stable elements that can be attributed also to the formula appear in each of Buke Palang Pintu performances. In understanding the changes emerging in the development of tradition, Sims and Stephens place tradition as an object present in the present but still related to the past. Tradition connects a group of people to previous generations, to ethnic and religious identity, and identifies them as a group of people with specific cultural behavior. But also be aware that the tradition also changed, either done consciously or unconsciously.

Sims and Stephens [1] view the change as a natural process of the dynamics of tradition. Changing traditions with new forms or ways should not be regarded as a mistake let alone perceived as destructive of tradition. This change is in fact just a way for members of the 
community to adapt their traditions to be more meaningful or more effective for them. Tradition may change, either because of its changing function or because of a change in taste. But performing a traditional practice in a new, slightly different way does not mean it's wrong or disrespectful of tradition. If there's a "new" way, it's likely that the members of the group have, consciously or unconsciously, adapted the tradition to be more meaningful and / or effective for them, as a current member of the group.

With the perspective that tradition is highly likely to change and adapt becomes more meaningful for the group of people who practice it, traditions can be viewed as something that has two sides of the coin: meaningful and valuable to the group so it deserves to be passed down from generation to generation; should also remain relevant and able to adapt to the development and change of society. Barre Toelken in The Dynamics of Folklore [5] states that every tradition has a dynamic and conservative element that allows tradition to adapt while maintaining its continuity with the past.

The conservative element-or by Vansina is called a fixed element-is an element in tradition that is static, fixed, and unchanged. Toelken said that conservative elements are determined by the community. Conservative elements have more power than just individual creativity. It deals with values and things that are considered symbolic by the community.

Based on observations of some Buke Palang Pintu shows, there are several conservative elements in this tradition which I then divide into two, elements and structures. Element refers to the element of the show that always appears: maen pukul, sike, berbalas pantun, and ngarak. While the structure refers to the performance structure as well as the structure of the berbalas pantun which are always fixed.

Maen pukul was referring to the local term used to refer to martial arts in Betawi culture. Pukul refers to moves that are dominated by hitting motions. While sike is a style in reading the verses of the Qur'an. In addition to the Qur'anic verse, in the sike readings are also recited the salutation of the Prophet. both of these elements--maen pukul and sike--are the conservative elements that always appear in the Buke Palang Pintu show as well as the two things that illustrate the principle of life of the Betawi people.

For Betawi people, it is a duty if a young man who wants to get married can go to school and can be ngaji. It can be a symbol for a man's ability as a head of household to protect his family. While it can be a symbol of the ability of the head of the family who understand the religion and will be able to educate his family.

Another element that always appears is a berbalas pantun. The dialogue in Buke Palang Pintu is done by interspersed with rhymes. Berbalas pantun is not stand alone but inserted in the form of a dialogue conducted by the spokesman of the groom and the bride's spokesperson. As seen in the conversation between the bride's spokesman who asked the purpose of the arrival of the following group of brides.

The last element that became a conservative element in Buke Palang Pintu is ngarak. Ngarak is a Betawi term used to call the procession accompanying the group of brides to the bride's residence to carry out the ceremony. This group of brides will be accompanied by the strains of musical instruments and the reading of salawat. Musical instrument that is commonly used is ketimpring tambourine, but appear also marawis even tanjidor in observation in field [6]. Ngarak not only appeared at the beginning of Buke Palang Pintu performances but also at 
the end of the show, which is when the groom has been accepted by the bride's representative and are invited into the bride house.

It is the creativity of expression in any given situation that Toelken characterizes as dynamic, the factors that keep the tradition vital [1]. Dynamic elements are closely related to creativity. From the Buke Palang Pintu show I saw in the wedding reception there were several dynamic elements that I noted:

\section{a. Performance time}

Buke Palang Pintu is no longer implemented before the marriage ceremony is held, but held as part of the wedding reception, after the marriage ceremony is done, and before the (new) married couple sit side by side in the aisle.

\section{b. Musical instrument}

At the wedding of Flower and Akmar, the musical instrument used in ngarak is a ketimpring tambourine. The use of tambourine ketimpring in accordance with some literature that I read. However, in Rian and Ulfa's wedding reception, the position of tambourine ketimpring as rebana parade bride was replaced by tanjidor. This is quite interesting considering that generally ketimpring tambourines are replaced by rebana marawis. The replacement of tambourine ketimpring with rebana marawis and tanjidor, based on the interview with the speakers, is the result of the difficult process of inheriting tambourine ketimpring. How to play it that tends to be more difficult than how to play other tambourines causes the rarity of people who can play ketimpring rebana. For the sake of Buke Palang Pintu tradition, the traders try to be creative with other musical instruments to accompany the procession of the pavement.

\section{c. Pantun}

The dialogue inserted by many pantuns and structures in the dialogue is a conservative element in Buke Palang Pintu. However, the pantun form itself is a dynamic element. The rules related to the structure of the dialogue also become a mnemonic device for the traders of Buke Palang Pintu tradition.

\section{CONCLUSION}

Each show has a structure. By Vansina [1] the structure is divided into external structures and internal structures. External structures divide performances as formal or informal texts, as well as free or fixed texts. While the internal structure refers to the various rules regarding the contents of the text. For example in the tradition of internal story genre stories can be identified by searching plot, episode, motif, background, and theme.

In addition to the performance structure, another conservative element in Buke Palang Pintu is the structure of dialogue. In general, the structure of the dialogue on Buke Palang Pintu can be divided into several sections. First, the opening section that contains greetings and greetings to the host. Secondly, the core part of which contains the delivery of the destination of arrival, notification of the first requirement, pantun silat containing ridicule to heat the opponent, and notification of the second condition. Third, the closing section which states acceptance from the host to the guest entourage.

Dynamic elements are closely related to creativity. From the Buke Palang Pintu show I saw in the wedding receptions between Bunga-Akmar and Rian-Ulfa, there were several 
dynamic elements that I noted, the execution time, the musical accompaniment, the fashion, the accessories, and the contents of the pantun.

Besides watching the Buke Palang Pintu show in the wedding ceremony, I also witnessed the Buke Pintu show during the celebration of PMI's Anniversary at Setu Babakan. Ever since I first saw this show, I've got the impression that this show is another form of Buke Palang Pintu tradition that is brought to the ceremonial realm. Buke Pintu's own term I got from interview with Door Cross art actor, Bang Awang, who also acts as a spokesman or pantun in the show. Buke Pintu refers to the adaptation of the Buke Palang Pintu tradition which is performed at ceremonial events such as opening ceremonies, welcoming guests, and inauguration.

The difference between Buke Palang Pintu and Buke Door I noted occurred in some form. First, the goal. If Buke Cross door is done in the framework of wedding ritual, Buke door is done for the purpose of mere entertainment. Second, duration. Given its purpose only as a ceremonial form that generally started an event, Buke Pintu only lasted about 7 minutes. This is because Buke Pintu is made as dense as possible and removes some parts inside Buke Palang Pintu. The inside of Buke Palang Pintu is much more dramatic because it is through several stages, when the winner of the bridegroom is lost several times by the winner of the bride. While in Buke Pintu, the scene at the time only shows the scene as necessary.

Third, the decrease in duration is also the result of the absence of sike in Buke Pintu. The absence of sike makes Buke Pintu shift from a tradition attached to Islamic symbols and values into traditions that are detached from religious values. This is because Buke Pintu can be held in various ceremonial events regardless of religious background in the event. However, Betawi's adherence with Islam still appears in the presence of salawat to accompany the entry of the guest entourage into the custom house.

The difference between the performance structure and the absence of the sike element that had previously become a conservative element in Buke Palang Pintu made Bang Awang feel more comfortable calling the show as Buke Door than Buke Palang Pintu. The non-use of the term "bar" also illustrates that Buke Pintu tradition only serves as mere entertainment, no longer symbolic.

\section{REFERENCES}

[1] S. MC and S. M, "Living Folklore: An Introduction to the Study of People and Their Traditions." Utah State University Press, Logan, Utah, 2005.

[2] P. MPSS and (ed.), Tradisi lisan Nusantara dan warisan budaya. Jakarta: Direktorat Kepercayaan Terhadap Tuhan Yang Maha Esa dan Tradisi, Kementerian Pendidikan dan Kebudayaan, 2015.

[3] Y. Z. Shahab, J. J. J. M. Wuisman, and P. J. M. Nas, "The Betawi house in Jakarta: The dynamics of an urban cultural tradition," in Indonesian Houses, Brill, pp. 597628.

[4] J. Vansina, Oral Tradition: A Study in Historical Methodology. London: Routledge \& Kegan Paul, 1965.

[5] B. Toelken, Dynamics of folklore. Colorado: University of Colorado Press, 1996.

[6] H. Spiller and P. Yampolsky, "Betawi and Sundanese Music of the North Coast of Java: Topeng Betawi, Tanjidor, Ajeng," Asian Music, vol. 30, no. 1, p. 205, 1998. 